\title{
Target Costing Implementation and Organizational Capabilities: An Empirical Evidence of Selected Asian Countries
}

\author{
Normah Omar, Suzana Sulaiman, Wee Shu Hui, Ibrahim Kamal Abdul Rahman, and Hussein H. \\ Hamood
}

\begin{abstract}
Target Costing (TC) is not only seen to be related to cost reduction. Instead, quality and functionality features, in similar extent, should be seriously perceived. Dynamic Capabilities (DCs) could affect organizational functions in relation to these objectives. This paper aims to examine the TC implementation and DCs in three Asian countries; Japan, Thailand and Malaysia. The findings through the proposed framework indicate that the DCs factors are a key to the right balance across the crucial elements of TC: cost reduction, quality, functionality, and lead time. The proposed framework could be a conceptual link between DCs factors and a successful implementation of TC.
\end{abstract}

Index Terms-Target costing, dynamic capabilities, Asian countries.

\section{INTRODUCTION}

In today's rapid changes of customers' expectations and more diversity of products, organizations endeavor is to implement an effective management control system for product costs whilst not sacrificing the other features; quality, functionality and lead time. Adopting Target Costing (TC) is mainly initiated as a cost management technique to drastically manage product features, cost, quality, and functionality. It was developed by TOYOTA in the beginning of the $1960 \mathrm{~s}$, and it has been used since that period by Japanese companies [1]. In TC literature, many studies have reported that the most important benefit of TC is to assist companies in making the trade-off between cost, quality and functionality (e.g. [2]-[6]. This could definitely depend on the Dynamic Capabilities (DCs) where organizational functions combine with cross-functional teams. Many relevant studies e.g. [7]-[10] assert that the DCs have been recognized as the most important factor for the success of TC implementation. Accordingly, recent attention of many manufacturing companies worldwide toward TC adoption has created a need to radically change their DCs to the way in which the TC can be implemented successfully.

While the conceptual link between TC and DCs is still simplistic, this paper aims to examine the TC implementation and DCs in three Asian countries; Japan, Thailand and Malaysia. The TC variables of the twelve organizational capabilities adapted from Human Resource Alignment Scorecard (HRAS) [11] have been examined and

Manuscript received August 26, 2013; revised November 9, 2013.

Normah Omar is with the Accounting Research Institute, Universiti Teknologi MARA, Malaysia (e-mail: normah645@salam.uitm.edu.my). compared between the three countries. The paper is organized as follows: Section II discusses the selected studies pertaining to the TC and DCs. Then, Section III presents and discusses the findings and finally the paper is concluded in Section IV.

\section{Previous Selected Studies}

Selected empirical studies pertaining to TC implementation have been reviewed. The studies were collected from different refereed journals in management accounting field carried out from 1991-2012. TC technique has been adopted worldwide whether in Japan or outside Japan. In tandem with global diffusion of TC implementation, some of Asian countries have increased their attention toward this approach to maintain their competitiveness globally. Since TC approach has been received a lower rank among other management accounting techniques until 2004, it has looked promising in the next five years as reviewed by [12]. While [2] found around 80 per cent of Japanese assembly companies have applied TC, [13] reveal that 70.3 per cent of Japanese manufacturing companies listed in Tokyo Stock Exchange adopt this technique. Similar to Japanese higher adoption of TC, [14] revealed a higher rank of TC adoption among Chinese companies; ranked 4 out of 39 sampled companies. In contrast, the adoption of TC in Thailand and Malaysian has received a lower rank than Japan and China. In Thailand, [14] revealed a medium rank of TC adoption among Thai companies, 16 out of 31 sampled companies, whereas in Malaysia TC has been ranked 20 out of 27 companies as addressed in the study conducted by [15] and the literature reviewed by [12].

Table I summarizes the main studies implicating TC implementation with its variables used in the three selected Asian countries; Japan, Thailand and Malaysia. However, in most of the studies reviewed, TC variables, identified as the main contributing factor for the success of TC implementation, are said to be related to the DCs. According to [8], organizations should evaluate three areas to determine its readiness to implement TC. These include: (1) organization's culture and infrastructure, (2) TC's principles, and (3) procedures and tools needed to support TC implementation.

In Japan, [10] consider the concept of DCs as a success factor for TC performance as they accumulated through the multi-level of knowledge within the organization. They reported that the reason for focusing on the DCs influencing TC adoption is that the TC is a dynamic system which 
connects different tools and techniques, and these capabilities would show different aspects of knowledge accumulated within the organization. However, in their study examining the relationship between these capabilities, as success factors, and the performance of TC among Japanese companies, DCs are classified into three capabilities; local capabilities, architectural capabilities, and process capabilities, based on the model proposed by [16].
They found that the architectural capabilities, such as management support, linkage to profit planning, and crossfunctional team, are the most important factors for the successful implementation of TC. They also found that the next important factor for the success of TC is the process capabilities, whereas the impact of local capabilities is found to be relatively weak on TC performance. These results are supported by results found by [2], [8], [9].

TABLE I: TARget Costing PRACTICES IN SELECTED ASIAN COUNTRIES

\begin{tabular}{|c|c|c|c|}
\hline Country & Article & TC practices & Variables used in TC practices \\
\hline Japan & $\begin{array}{l}\text { Monden \& Hamada } \\
\text { (1991); } \\
\text { Kato (1993); } \\
\text { Tani et al. (1994); } \\
\text { Tani (1995); } \\
\text { Cooper \& Slagmulder } \\
\text { (1997); } \\
\text { Feil et al. (2004); } \\
\text { Huh et al. (2008) }\end{array}$ & $\begin{array}{l}\text { - Higher ratio of variable } \\
\text { costs than fixed costs } \\
\text { - The close linkage between } \\
\text { TC and Kaizen costing } \\
\text { - The active role of MAS } \\
\text { - Dynamic capabilities } \\
\text { - Factors influencing TC }\end{array}$ & $\begin{array}{l}\text { - Environmental uncertainty - intensity of competition - nature } \\
\text { of customers } \\
\text { - Organizational structure } \\
\text { - Customers' needs towards products characteristics } \\
\text { - Influential powers of managers: sales managers - product } \\
\text { planning manager - product managers - purchasing managers } \\
\text { - production engineering managers } \\
\text { - Market competition - timely introduction - technological } \\
\text { innovation } \\
\text { - Product strategy - suppliers-based strategy - products } \\
\text { characteristics } \\
\text { - Architectural capabilities - process capabilities - local } \\
\text { capabilities }\end{array}$ \\
\hline Thailand & $\begin{array}{l}\text { Chongruksut (2009); } \\
\text { Sumkaew et al. (2012); } \\
\text { Visedsun\&Terdpaopong } \\
(2012)\end{array}$ & $\begin{array}{l}\text { - TC characteristics } \\
\text { - TC performance outcome } \\
\text { - TC key success factors } \\
\text { - TC to cost management } \\
\text { - TC effect }\end{array}$ & $\begin{array}{l}\text { - Reliability and expertise of employee } \\
\text { TC outcome: quality improvement - cost reduction - lead } \\
\text { time - customer need of product features - timely } \\
\text { introduction - waste reduction - departments involved - } \\
\text { design/development technology - design-to-cost - cost } \\
\text { reduction to engineer efforts - raw materials reduction - } \\
\text { design changes - upstream cost reduction } \\
\text { - Success factors: top management support - information } \\
\text { system - suppliers participation - cooperation between } \\
\text { departments - empowered managers - cross functional team - } \\
\text { sharing information - delegation of power/responsibility - } \\
\text { linkages to profit - new technology to materials/R\&D - } \\
\text { technology to product quality - functional knowledge of } \\
\text { teams - knowledge about costs }\end{array}$ \\
\hline Malaysia & $\begin{array}{l}\text { Normah et al. (2002); } \\
\text { Abd Rahman et al. } \\
(2003) \text {; } \\
\text { Mahfar \& Omar (2004); } \\
\text { Sulaiman et al. (2004) }\end{array}$ & $\begin{array}{l}\text { - TC practice has not been } \\
\text { specifically addressed in } \\
\text { the literature }\end{array}$ & $\begin{array}{l}\text { - No specific variables identified (general surveys on } \\
\text { management accounting practices) }\end{array}$ \\
\hline
\end{tabular}

In Thailand, the TC variables shown in Table I are seen to be main contributing variables for TC implementation especially those related to the common TC objectives. Some of these variables are found in Japan but others are found to be specified to the Thai companies' structure. This is as mentioned by [16] and [17] that the most of the variables are adopted from previous literature. In contrast to the two Asian countries; Japan and Thailand, the surveys conducted in Malaysia to date are generally related to management accounting practices as an overall. Hence, the TC variables have not been specified, and this is an incentive for this study to be focusing on Malaysia in a comparative way with other Asian countries included and reviewed in this paper. However, the most interesting $\mathrm{TC}$ variables found throughout the two Asian countries reviewed are those related to environment factors that only focused by Japanese companies but not considered in the others.

\section{ReseARCh Methodology}

\section{A. Research Model}

For the purpose of this study and based on the literature reviewed, the research model employed includes the effect of DCs factors described as TC variables, company strategy, TC implementation decision, company size and organizational performance.

Fig. 1 shows the research model employed in which the TC variables are an exogenous variables to the TC implementation decision which is in turn an exogenous variable to organizational performance.

\section{B. Sample and Procedures}

For Japan and Thailand, the data was obtained from the recent study conducted in both countries. For Malaysia, the study population consisted 360 manufacturing company obtained from Federation of Malaysian Manufacturers (FMM) 2012. The respondents targeted were the $\mathrm{CEO} / \mathrm{GM} / \mathrm{COO} / \mathrm{MD}$, senior managers, assistant managers and relevant executives. A number of 515 questionnaires were distributed by hand and after many phone calls and SMS, personal visits, and emails during seven months interval, a total of 190 questionnaires were collected. Due to unusable answers of some questions and fully/partially sections uncompleted, another 14 questionnaires were eliminated. As a result, the number of responses was decreased to 176 reaching the net response rate of $34 \%$. 
This response rate is considerably satisfied compared with relevant studies on management accounting area conducted in Malaysia.

\section{RESUlts}

Descriptive Statistics and Factor Analysis was used to describe the effect of DCs on the decision made to implement TC and organizational performance and evaluate the DCs variables from the extent to which these variables can be explained by small groups of factors.

\section{A. Target Costing Practices \\ 1) The use of target costing}

In tandem with global diffusion of TC implementation, some of non-Japanese countries (e.g. Thailand, China, India, Singapore and Malaysia) have increased their attention towards this approach to maintain their competitiveness. Since TC approach has been received a lower rank among other management accounting techniques until 2004 in such countries, it has looked promising in the next five years as reviewed by [12].

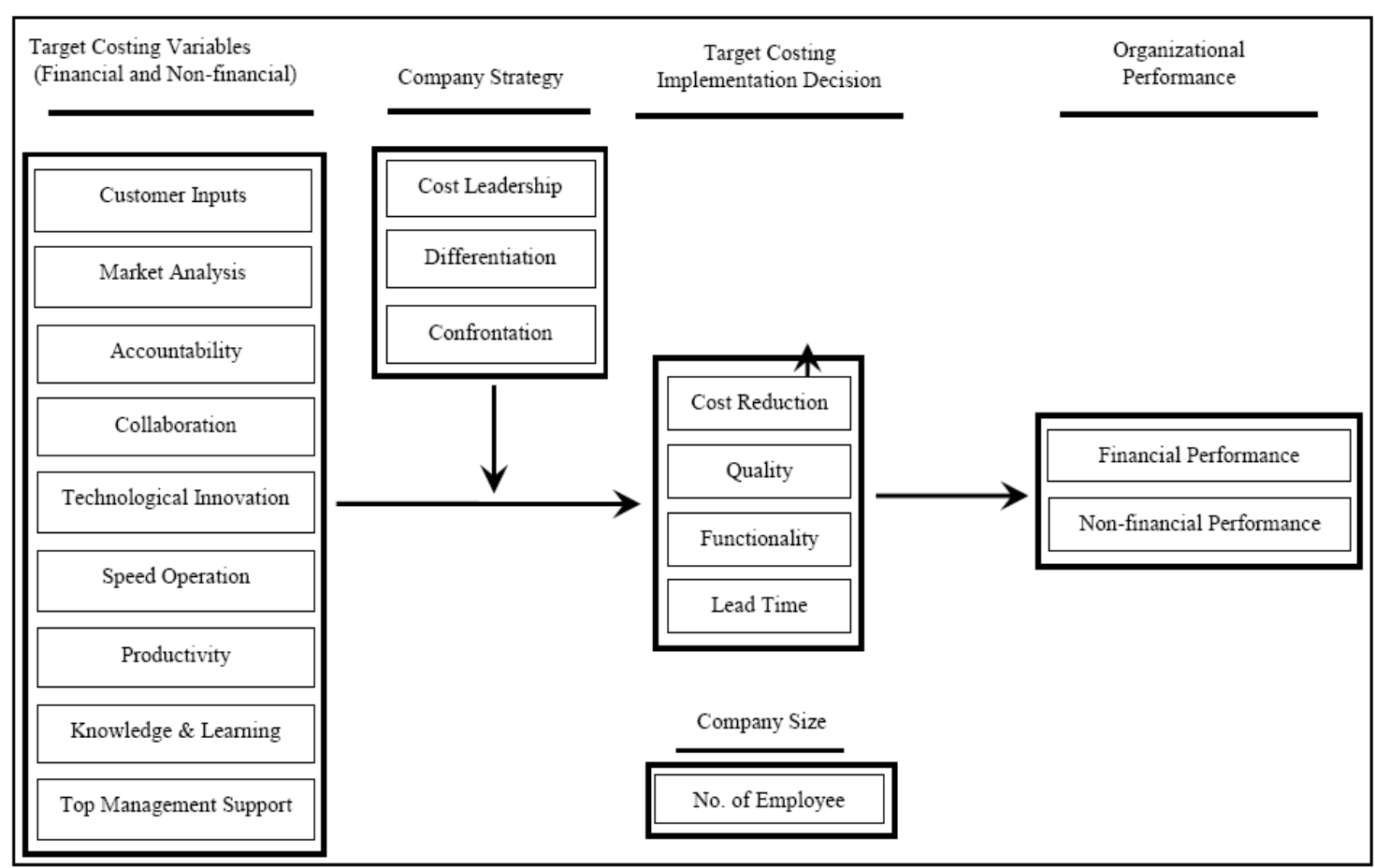

Fig. 1. Research model.

Table II presents the percentage use/rank of TC in the three Asian countries selected for this study. Around 80 per cent of Japanese assembly companies have applied TC for more than 40 years ([2], [10], [13]). In contract, the adoption of TC in both Thailand and Malaysian countries has received a lower rank than Japan. It has been ranked 30 out of $37(43.9 \%)$ companies in Thailand as reported by [17], whereas in Malaysia, TC has been ranked 20 out of 28 companies in terms of importance, and appeared among management accounting techniques that had mean score of less than 2.00 out of 3.99 as addressed in the study conducted by [15].

\section{2) Departments involved}

TABLE II: THE USE OF TARGET COSTING

\begin{tabular}{lll}
\hline \hline \multicolumn{1}{c}{ Country } & Percentage of use/Rank & Average time period \\
\hline \hline 1. Japan (2008) & $80 \%$ & More than 40 year \\
2. Thailand (2012) & $43.9 \%$ & More than 10 year \\
& & \\
3. Malaysia (2004) & 20 out of 28 & More than 5 year \\
\hline \hline
\end{tabular}

All the sampled companies in the three countries consider the active role of cross-functional team in TC implementation. According to [8], inside TC participants include marketing, purchasing, production, servicing and accounting, whereas the outside participants include suppliers, dealers, distributers, and recyclers. A distinct difference of TC practice between Japan and other selected Asian countries are specifically highlighted in the active role of Target Costing Management (TCM) team which has not been found in non-Japanese context. According to [13], TCM is concerned with the achievement of target costs simultaneously with planning, development and detailed design of new products. In addition, Malaysian companies give much importance to quality department that ensure customers' expectations. This department was ignored in Japanese and Thai studies.

\section{3) Company strategy}

TABLE III (A): COMPANY STRATEGY

\begin{tabular}{lllcc}
\hline \hline & \multicolumn{1}{c}{$\begin{array}{c}\text { Japan } \\
\text { Frequency } \\
(\%)\end{array}$} & $\begin{array}{c}\text { Thailand } \\
\text { Frequency } \\
(\%)\end{array}$ & $\begin{array}{c}\text { Malaysia } \\
\text { Frequency } \\
(\%)\end{array}$ \\
\hline \hline 1. $\begin{array}{l}\text { Cost } \\
\text { Leadership }\end{array}$ & $\begin{array}{l}\text { Not highly } \\
\text { adopted }\end{array}$ & $10(17.6 \%)$ & $15(8.5 \%)$ \\
2. & Differentiation & $\begin{array}{l}\text { Not highly } \\
\text { adopted }\end{array}$ & $22(38.6 \%)$ & $41(23.3 \%)$ \\
3. Confrontation & Highly adopted & $25(43.8 \%)$ & $120(68.2 \%)$ \\
\hline \hline
\end{tabular}


Details of the descriptive statistics for the strategy that the company followed are shown in Table III (A). Three types of strategies; cost leadership, differentiation, and confrontation strategy; were investigated to determine the moderating effect on the DCs and TC implementation. The results of frequencies reveal that the majority of sampled companies in both countries Thailand and Malaysia (43.8\% and $68.2 \%$ respectively) tend to employ confrontation strategy. According to [3], confrontation strategy is mostly suitable for TC implementation. [4] found that the six studied Japanese companies (Nissan, Toyota, Komatsu, Olympus, Sony, and Topcon) were in intensely competitive industries and have adopted confrontational strategy, and then they have well developed and elaborate TC technique. The results generally indicate that the confrontation strategy has active effect when determining the contributing TC variables to the successful implementation. The higher percentage of adoption of such strategy in Malaysian in particular indicates the well readiness of Malaysian companies to implement TC technique.

\section{4) Company size}

By considering the company size in this study, the success implementation of TC can be affected by this variable. In the literature, however, the TC implementation is biased toward large companies as these companies have adequate financial and personal resources. Therefore, the company size, defined by number of employees, was used as control variables in the attempt to control the effect of these variables on the company's decision made to implement TC approach. The results indicate that there were significant differences in companies' tendency towards TC impalement with their size represented by number of employee at .05 level of significance in all countries selected; Japan, Thailand and Malaysia (sig. value $=0.031$; 0.036; 0.029 respectively).Target Costing Variables.
Table III (B) below presents the descriptive statistics of TC variables represented as DCs factors. The results in general indicate that the TC variables once deciding to implement TC approach are shown to be significantly applicable (mean values > 3). This however supports the study assumption. The average mean of 3.97 indicates the higher possibility effect of DC son TC implementation in Japan followed by Malaysia and Thailand based on the fivelikert scales used. However, the results show high mean values for customers' inputs in Japan than Thailand and Malaysia (4.15, 4.57 and 3.45 respectively). This indicates that the initial focus of TC implementation among Japanese companies was towards customers' needs including desired selling price and satisfied product features. In addition, the higher mean value of market analysis in Japan (mean $=4.19$ ) than other countries supports the main concept of TC as initially described by Japanese literature as a market oriented selling price method. The third party diffusion among Malaysian companies caused the lowest mean value of market analysis factor (mean $=2.77$ ) than other countries. Malaysian companies aggressively depend on the third party in identifying the product features including the price negotiation but not unfortunately to the market research.

The other interesting result is that related to the speed operation factor which concern on the frequent cost estimation when attempt to achieve allowable TC. Japanese companies give a significant concern on the effect of frequent cost estimation on product quality and timely introduction of the products to the market. Meanwhile, top management support has been highly found to be an effective factor for TC implementation (e.g. [10], [20], [21], [16], [17]). The results found in all countries support this argument (mean $>4$ in Japan and Thailand and Mean $>3$ in Malaysia).

\begin{tabular}{|c|c|c|c|c|c|c|c|c|c|}
\hline \multirow{2}{*}{ TC Variables } & \multicolumn{3}{|c|}{ Japan } & \multicolumn{3}{|l|}{ Thailand } & \multicolumn{3}{|c|}{ Malaysia } \\
\hline & Mean & S.D. & F. Loading & Mean & S.D. & F. Loading & Mean & S.D. & F. Loading \\
\hline Customers Inputs & 4.15 & 0.89 & 0.874 & 4.57 & 0.78 & 0.886 & 3.45 & 0.75 & 0.718 \\
\hline Market Analysis & 4.19 & 0.64 & 0.751 & 4.03 & 0.87 & 0.851 & 2.77 & 0.88 & 0.691 \\
\hline Accountability & 3.64 & 0.90 & 0.666 & 3.63 & 0.99 & 0.838 & 3.01 & 0.79 & 0.667 \\
\hline Collaboration & 3.50 & 0.76 & 0.533 & 3.91 & 0.83 & 0.893 & 3.11 & 0.82 & 0.741 \\
\hline $\begin{array}{l}\text { Technological } \\
\text { Innovation }\end{array}$ & 3.92 & 0.70 & 0.627 & 3.65 & 0.86 & 0.843 & 3.30 & 0.79 & 0.717 \\
\hline Speed Operation & 3.32 & 0.78 & 0.478 & 3.63 & 0.99 & 0.856 & 2.93 & 0.91 & 0.673 \\
\hline Productivity & 3.87 & 0.90 & 0.541 & 3.14 & 0.91 & 0.943 & 3.29 & 0.79 & 0.778 \\
\hline $\begin{array}{l}\text { Knowledge \& } \\
\text { Learning }\end{array}$ & 4.11 & 0.63 & 0.498 & 3.60 & 0.98 & 0.924 & 3.09 & 0.88 & 0.616 \\
\hline $\begin{array}{l}\text { Top Management } \\
\text { Support }\end{array}$ & 4.57 & 0.67 & 0.588 & 4.50 & 0.73 & 0.917 & 3.22 & 0.83 & 0.680 \\
\hline Average & 3.97 & & & 3.81 & & & 3.12 & & \\
\hline
\end{tabular}

Notes: the mean values are calculated based on the following:

Japan: 5-point scales: $1=$ none; $2=$ slight; $3=$ moderate; $4=$ substantial; 5 = extensive.

Thailand: 5-point scales: $1=$ lest important; $2=$ low important; $3=$ natural; $4=$ important; $5=$ most important.

Malaysia: 5-point scales: $0=$ not sure; $1=$ very low; $3=$ slightly low; $4=$ slightly high; $5=$ extremely high.

\section{B. Target Costing Implementation Decision}

For the purpose of this study, the main objectives of TC implementation decision are cost reduction, quality, functionality, and lead time. The first three objectives (cost reduction, quality, and functionality) are the three crucial elements of TC presented in [3] Survival Triplet framework, whereas the forth objective (lead time) is extended by [20] to the [3] Survival Triplet framework. This to see the extent 
to that the TC variables (DCs) could reach the targeted balance among all TC objectives. Table IV and V summarizes the descriptive statistics of TC objectives. The results show high mean values for the cost reduction objective in Japan and Malaysia (mean $=4.02,3.35$ respectively), whereas in Thailand the realization of product concept in terms of quality and functionality was the main objectives of TC implementation decision (mean $=3.76$, 3.63 respectively). The higher realization of product quality and functionality among Thai companies is consistently found in their high consideration of customers' inputs and market analysis (see Table III). As such, the realization of product cost reduction objective among Japanese companies is consistently found to be higher (see Table III also). In contrast, in Malaysian companies, this consistency between DCs factors and TC objectives was found in some of TC variables and not found in the others (see Table III also). This can be justified that the Malaysian companies may have uncomfortable feelings towards TC concept that the cost reduction may lead to conflict with other product features especially the high pressure to meet strict customers' expectations that need higher costs.

TABLE IV: DESCRIPTIVE STATISTICS AND FACTOR ANALYSIS: TARGET COSTING IMPLEMENTATION DECISION

\begin{tabular}{|c|c|c|c|c|c|c|c|c|c|}
\hline \multirow{2}{*}{$\begin{array}{l}\text { TC Implementation } \\
\text { Decision }\end{array}$} & \multicolumn{3}{|c|}{ Japan } & \multicolumn{3}{|c|}{ Thailand } & \multicolumn{3}{|c|}{ Malaysia } \\
\hline & Mean & S.D. & F. Loading & Mean & S.D. & F. Loading & Mean & S.D. & F. Loading \\
\hline Cost Reduction & 4.02 & .59 & .604 & 3.42 & .97 & .980 & 3.35 & .49 & .571 \\
\hline Product Quality & 3.47 & .69 & .697 & 3.76 & .84 & .975 & 3.44 & .57 & .618 \\
\hline Product Functionality & 3.54 & .68 & .627 & 3.63 & .96 & .974 & 3.24 & .61 & .675 \\
\hline Lead Time & 3.01 & .69 & .763 & 3.50 & .90 & .964 & 3.20 & .63 & .495 \\
\hline Average & 3.51 & & & 3.58 & & & 3.31 & & \\
\hline
\end{tabular}

Notes: the mean values are calculated based on the following:

Japan: 5 -point scales: $1=$ none; $2=$ slight; $3=$ moderate; $4=$ substantial; $5=$ extensive.

Thailand: 5-point scales: $1=$ lest satisfied; $2=$ low satisfied; $3=$ natural; $4=$ satisfied; $5=$ most satisfied.

Malaysia: 5-point scales: $0=$ not sure; $1=$ not at all important; $3=$ slightly important; $4=$ generally important; $5=$ extremely important.

TABLE V: DESCRIPTIVE STATISTICS AND FACTOR ANALYSIS: ORGANIZATIONAL PERFORMANCE

\begin{tabular}{|c|c|c|c|c|c|c|c|c|c|}
\hline \multirow{2}{*}{$\begin{array}{l}\text { TC Implementation } \\
\text { Decision }\end{array}$} & \multicolumn{3}{|c|}{ Japan } & \multicolumn{3}{|c|}{ Thailand } & \multicolumn{3}{|c|}{ Malaysia } \\
\hline & Mean & S.D. & F. Loading & Mean & S.D. & F. Loading & Mean & S.D. & F. Loading \\
\hline Financial Performance & 4.02 & .59 & .814 & 3.52 & .88 & .781 & 3.44 & .65 & .839 \\
\hline Non-Financial Performance & 3.89 & .79 & .697 & 2.96 & .92 & .882 & 3.37 & .67 & .824 \\
\hline Average & & & & & & & & & \\
\hline
\end{tabular}

Notes: the mean values are calculated based on the following:

Japan: 5 -point scales: $1=$ none; $2=$ slight; 3 = moderate; $4=$ substantial; $5=$ extensive.

Thailand: 5 -point scales: $1=$ strongly disagree; 2 = disagree; $3=$ natural; 4 = agree; $5=$ strongly agree.

Malaysia: 5 -point scales: $0=$ not sure; $1=$ no impact; $3=$ slight low impact; $4=$ slight impact; $5=$ strong impact.

\section{Target Costing Implementation and Organizational Performance}

Table V presents the descriptive statistics of organizational performance including financial and nonfinancial performance. The results show unexpected of financial performance against non-financial performance in Thailand (mean $=3.52 ; 2.69$ respectively). Meanwhile, the high mean value of financial performance in Japan is belonging to the high tendency of Japanese companies to TC Variables from financial perspective (see Table III and Table IV). On the other hand, Malaysian companies consider the impact of the right balance of TC variables on both organizational performance; financial and no-financial. The results conclude that the multidimensional effect of TC variables was found in both dimensions of organizational performance.

\section{CONCLUSION AND DisCUSSION}

This paper aims to examine the TC implementation and DCs in three selected Asian countries; Japan, Thailand and Malaysia with a considerable focus on Malaysia than others. The gap found in the literature is that the conceptual link between TC and DCs is still simplistic. The findings of the study confirm the successful effect of TC variables (DCs) on the TC implementation decision and ultimately the organizational performance. The results show that the most focus of TC technique was not only seen to be related to the cost reduction. Instead, quality and functionality features, in similar extent, were perceived and linked on relevant DCs factors. This particularly requires serious and an effective integration of relative DCs to establish future customers' expectations toward company's products.

The study has supported the findings of the existing literature regarding the TC implementation in the other three Asian countries included in this study. [23] consider TC as an integrated mechanism that ties different functional units in a company together into one cohesive system. Moreover, [21] assert that the TC is supported by many techniques. This is a major factor for its successful application in Japanese companies, such as Kaizen Costing with TC [19] and also TC with ABC in US companies [20]. In addition to Japanese experience in integrating Kaizen Costing with TC, there are many factors which help Japanese companies to develop and implement TC successfully [19]. The proposed framework in this study might be one of these ways that could link the DCs as an influential factor for a successful TC implementation.

This study has added new knowledge to the TC literature 
in Asian selected countries such as Malaysian as not being widely implemented. Same with other research, this study has some of limitations that need to be highlighted in the future. Firstly, the sample of study is only concerned on manufacturing industry due to the some specific aspects of such industry. Hence, the outcome of cannot generally be used and applied to other service and financial industry. In the future, it is hoped to extend this study to include other industries, such as financial and services industries. Secondly, the study is empirically conducted only on Malaysian country and compared with the studies' findings of the other two selected Asian countries. In future research, a comparative study should be empirically conducted to include different countries. This is to point out whether the environmental effect coupled with DCs in those countries could support TC implementation.

\section{REFERENCES}

[1] P. Afonso, M. Nunes, A. Paisana, and A. Braga, "The influence of time-to-market and target costing in the new product development success," Int. J. Production Economics, vol. 115, pp. 559-568, 2008.

[2] Y. Kato, "Target costing support systems: Lessons from leading Japanese companies," Management Accounting Research, pp. 33-47, 1993.

[3] R. Cooper, When Lean Enterprises Collide: Competing through Confrontation, Boston, Harvard Business School Press, 1995.

[4] R. Cooper and R. Slagmulder, Target Costing and Value Engineering Portland, Oregon, Productivity Press, 1997.

[5] R. Cooper and R. Slagmulder, "Develop profitable new products with target costing," Sloan Management Review, ABI/INFORM Global, vol. 40 , no. 4 , pp. $23,1999$.

[6] C. Ax, J. Greve, and U. Nilsson, "The impact of competition and uncertainty on the adoption of target costing," Int. J. Production Economics, vol. 115, pp. 92-103, 2008.

[7] P. Joshi, "The international diffusion of new management accounting practices: the case of India," Journal of International Accounting, Auditing and Taxation, vol. 10, pp. 85-109, 2001.

[8] D. W. Swenson, T. E. Buttross, and I.-W. Kim, "Using the CAM-I Diagnostic to evaluate readiness for target costing," Cost Management, ABI/INFORM Global, vol. 19, no. 3, pp. 41, 2005.

[9] M. Kocsoy, K. Gurdal, and M. E. Karabayir, "Target Costing in Turkish Manufacturing Enterprises," European Journal of Social Sciences, vol. 7, no. 2, pp. 92-105, 2008

[10] S. Huh, K. H. Yook, and I. W. Kim, "Relationship between organizational capabilities and performance of target costing: An empirical study of japanese companies," Journal of International Business Research, vol. 7, no. 1, pp. 91-107, 2008.

[11] Ulrich, Wilhelm, and Solow, "Twelve organizational capabilities," Human Resource Alignment Scorecard (HANS), 2003.

[12] M. Sulaiman, N. N. Ahmad, and N. Alwi, "Management accounting practices in selected Asian countries: A review of the literature," Managerial Auditing Journal, ABI/INFORM Global, vol. 19, no. 4, pp. 493, 2004.
[13] T. Tani, H. Okano, N. Shimizu, Y. Iwabuchi, J. Fukuda, and S Cooray, "Target cost management in Japanese companies: Current state of the art," Management Accounting Research, vol. 5, pp. 67-81, 1994.

[14] H. C. Huang, M. C. Lai, M. C. Kao, and Y. C. Chen, Target Costing, Business Model Innovation, and Firm Performance: An Empirical Analysis of Chinese Firms, 2012.

[15] R. Mahfar and N. Omar, "The current state of management accounting practice in selected malaysian companies: an empirical evidence," A paper presented at the International Business Management Conference, in Universiti Tenaga Nasional, Malaysia, pp. 50-61, 2004

[16] N. Sumkaew, L. Y. J. Liu, and J. Laren, "Management accounting practices in Thailand," presented at Asia pacific Management Accounting Association Conference, in Xiamen University, China, 2012.

[17] N. Visedsun and K. Terdpaopong, "Preliminary survey of implementing target costing in the Thai manufacturing firms," presented at Asia pacific Management Accounting Association Conference, in Xiamen University, China, 2012.

[18] W. Chongruksut "Organizational culture and the use of management accounting innovation in Thailand," RU. Int. J., vol. 3, no. 1, pp. 113 125,2009

[19] P. Feil, K. H. Yook, and I. W. Kim, "Japanese target costing: A historical perspective," International Journal of Strategic Cost Management, pp. 10-19, 2004.

[20] M. Souissi and K. Ito, "Integrating target costing and the balanced scorecard," The Journal of Corporate Accounting and Finance, vol. 15 , no. 6 , pp. $57,2004$.

[21] Y. Monden and K. Hamada, "Target costing and kaizen costing in Japanese automobile companies," Journal of Management Accounting Research, vol. 3, pp. 16-34, 1991.

[22] G. Cokins, "Integrations of target costing and ABC," Journal of Cost Management, vol. 6, no. 4, pp. 13-22, 2002.

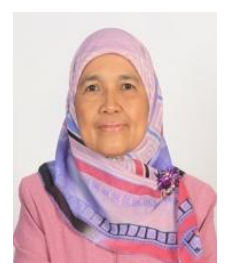

Normah Omar is the director of the Accounting Research Institute (ARI), a Higher Institution Centre of Excellence (HICoE) which is recognized and funded by the Ministry of Higher Education, Malaysia. Prof Normah's research interest is in the area of forensic accounting and financial criminology. As a proponent of applied research, Prof Normah has completed a lot of collaborative research works with government agencies, professional bodies, regulators, non-government organizations and the corporate sectors in Malaysia. To mention a few, she has successfully completed research projects such as Corporate Governance Rating; The Development of Financial Fraud Red Flags and the Governance of Non Profit Organizations (NPO) within the AML-CFT Regime. Currently Prof Normah is heading one of the Malaysian Institute of Integrity's (MII) collaborative research projects on Corporate Integrity System. To date, Prof Normah sits as editors of seven international refereed journals. She is also the vice president and founding committee member of the Asia-Pacific Management Accounting Association (APMAA) which is based in Japan. 